\title{
Empowerment of Women Micro Entrepreneurs under NRLM: A Critical Analysis.
}

\author{
Dr. Soumitra Sarkar \\ Assistant Professor of Commerce \\ Alipurduar College
}

\begin{abstract}
Microfinance provides low cost finance and non-financial services to the vulnerable rural poor of the country in order to capacitate them to generate income through their microenterprises, which help them to uplift their financial strength. The new paradigm of microfinance put emphasis on women through Self Help Groups (SHGs) in order to improve their living standard by empowering them in all respect, and it helps to become an enterprising women. Taking the cognition of NABARD's pioneering effort, in the same vein, Government of India launched Swarna Jayanti Gram Swarojgar Yojana (SGSY) in1999 to make easy access to the subsidised credit for the enterprising women. Millions of SHGs were formed under SGSY around the nation, and now, it is restructured and renamed as National Rural Livelihood Mission (NRLM). The principal objective of this study is to gauge the root causes of the obstacles which are facing by the women microfinance beneficiaries in their socio-economic empowerment process. This study concentrates on the major areas of empowerment of enterprising women. Adequate amount of data was collected through survey with the 280 NRLM beneficiaries as the randomly selected sample respondents. The outcome of the study shows that majority of the beneficiaries are involved in traditional sector i.e. chira muri making and agriculture based products and they use to sale it in their local market, mostly on credit. Naturally the women beneficiaries under NRLM are lived in a measurable condition. To substantiate this finding appropriate case vignette was formulated on the basis of personal interview with the beneficiaries in several occasions.
\end{abstract}

Key Words: Microfinance, Self Help Groups, Microenterprises, Bank-Linkage, NRLM, Empowerment.

\section{Introduction}

In most developing countries, gender inequality is a major obstacle to accomplish the Millennium Development Goals. In reality, achieving the goals will not be feasible without closing the gaps between women and men in terms of capacities, access to resources and opportunities, and vulnerability to violence and conflict (United Nations Industrial Development Organization, 2009). The fact that five of the eight Millennium Development Goals (MDGs) concern health and education signals the importance of welfare in development. The empowerment of women becomes a powerful agency to improve welfare and human development. It is argued that empowering women improves the well-being of the household and lead to better outcomes for children (Kabeer, 2003).

Micro Finance as a tool of poverty alleviation and women empowerment has gained acceptance in development dialogue the world over. There is an acute need among the poor for credit, both for consumption and production, which often forms the declining line between survival and succumbing to poverty. It has been found that besides food, credit is also needed for health, housing education. These needs are also critical for survival ( Zeller, 2000).

One of the powerful approaches to women empowerment and rural entrepreneurship is the formation of Self Help Groups (SHGs) especially among women. This strategy had fetched noticeable results not only in India and Bangladesh but world over. The success of SHGs as a development tool depends on the availability of Microfinance.

Self help groups (SHGs) and women's groups in particular, represent a form of intervention that is a radical departure from most current programmes. They are effective strategy for poverty alleviation, human development and social empowerment. They offer grassroots participatory implementation that is demand driven by „,beneficiaries" who, in other projects, often find themselves receiving goods or services in a manner that is opaque and impersonal (ibid).

Governmental and nongovernmental organizations in developing countries have introduced microfinance programs before couple of decades which offering financial services to low income households, specifically targeting women. This was based on the promise that women in poor households are more likely to be credit constrained, and hence less able to undertake income-earning activities. Access to credit has received even greater attention in the context of poverty reduction and women empowerment objectives. With the aim to 
meet the Millennium Development Goals and microfinance programs' role in supporting it, there has been an increasing expectation on their impact on women empowerment (Pitt et. al, 2006).

\section{Conceptual Background}

The new buzzword, "empowerment" has caught interest of the researchers, practitioners and particularly disadvantaged citizens of all nations especially after the establishment of Millennium Development Goal (MDG) in 2002. The term empowerment has been defined by vast people of diversified field from different dimensions. It will be prudent to highlight the wide range of definition of empowerment in this regard. Due to paucity of word, two of the important definition can be quoted in this regard.

The World Bank's Empowerment and Poverty Reduction: A sourcebook, defines empowerment in its broadest sense as the "expansion of freedom of choice and action" (Narayan, 2002). United Nations (2001) defines empowerment as the processes by which women take control and ownership of their lives through expansion of their choices. Kabeer's (1999) view of empowerment refers to the processes by which those who have been denied the ability to make choices acquire such ability. The fundamentals of empowerment have been defined as agency (the ability to define one's goals and act upon them), awareness of gendered power structures, self-esteem and self-confidence.

Mayoux's (2000) definition of empowerment relates more directly with power, as "a multidimensional and interlinked process of change in power relations". It consists of: (1) 'Power within', enabling women to articulate their own aspirations and strategies for change; (2)'Power to', enabling women to develop the necessary skills and access the necessary resources to achieve their aspirations; (3) 'Power with', enabling women to examine and articulate their collective interests, to organize, to achieve them and to link with other women and men's organizations for change; and (4) 'Power over', changing the underlying inequalities in power and resources that constrain women's aspirations and their ability to achieve them. These power relations operate in different spheres of life (e.g., economic, social, political) and at different levels (e.g., individual, household, community, market, institutional). Therefore it is clear from the above mentioned definitions that 'empowerment' is a multifaceted concept and indeed, it has four major dimensions - Financial, Social, Political and Cultural.

\section{Microfinance And Women Empowerment}

The status of women in modern microfinance programme can be gauged through the impact study. A significant amount of literature has been produced related to SHG and Women Empowerment. A very few of them can be quoted here. There is extensive evidence that microfinance has a positive impact on the first Millennium Goal: that the number of people living in extreme poverty (defined as those living on less than $\$ 1$ per day) will be reduced by half between 1990 and 2015 .

Zaman (1999) argued that greater access to resources via micro credit enhanced a women's control over her assets. The control which a woman has over her assets is measured by, amongst other things, her ability and right to sell assets on the basis of her own personal choice. Carloni (1998) found that credit programs were more successful than income-generating projects in having a genuine impact on women's economic status.

Amin and Pebley (1994) observed that women believed that receiving microcredit loans reduced their chances of abandonment. Banu et al., (2001) found that BRAC had been able to bring about considerable changes in the lives of its female beneficiaries by facilitating their material, perceptual and relational pathways to empowerment, both at the individual and households levels.

Sultana (1988) in her study in Bangladesh concluded that women's group formation, regular savings and income, new knowledge, consciousness raising and group mobilization can together create an alternative to women's traditional condition and contribute to women's higher economic status. Montgomery (1996) stated that a group could positively impact qualitative dimensions of poverty and contributes to the women empowerment. According to Sridharan, Damayanty (1997) argued that the SHGs bring out the capacity of women in moulding the community in right perspective and explore the initiative of women in taking up entrepreneurial ventures. Murgan and Dharmalingam (2000) add that empowerment of women through Self Help Groups would lead to benefits not only to the individual women and women groups but also for the family and community as a whole through collective action for development. Pattanaik (2001) found that empowering women with property right and with savings and investment facilities contributed much more to the household income. Dhar \& Sarkar (2006) found that there has been some advancement in household rights of the women after joining SHGs. Dubhashi (2002) found out that all members of the SHGs are much more economically stable, active and successful today. Kulkarni. (2002) found that formation of SHG is not the end in itself but the means to facilitate the process of women empowerment. Rangi, Sidhu \& Singh (2002) that the additional income generated with the help of SHGs have provided them big moral support and will to bring new changes in the rural economy of the state as well as to the country in future. Sarkar (2005) found that women micro entrepreneurs in North Bengal have profitably taken up non-traditional economic activities, which have increased their economic benefits. Vijayanthi (2002) found increases in empowerment and levels of awareness 
creation, decision-making and self and group empowerment among women mobilizing into self-help groups. Panda \& Mohanthi (2003) found that in the light of economic empowerment of women, SHG is a novel initiative in providing easy credit to the poor vulnerable sections of society. Manimekalai (2004) found that SHGs create an awareness of the various opportunities of self-empowerment through micro enterprises and makes women economically empowered. Sen (2003) found that access to credit has a positive impact on income and physical quality of life but it is difficult to establish the extent of impact of social empowerment.

There is ample evidence to support the positive impact of microfinance on economic empowerment of microfinance beneficiaries, especially women, as it relates to fully six out of seven of the Millennium Goals. In particular, there is overwhelming evidence substantiating a beneficial effect on income smoothing and increases to income. There is less evidence to support a positive impact on social, cultural, political and other issues of women.

Modern microfinance movement has been started in India in 1999 after the initialisation of SHG-Bank Linkage programme of NABARD followed by SGSY of Government of India. This movement in India has become matured since it's more than a decade long journey with much vigour. Till the end of 2014 , more than three millions SHGs are operating in India where on an average more than five crores beneficiaries are involved. Researcher, Academicians and practicing organisations have been undertaken impact measurement studies from different the corner of India and world as well. Most of the impact studies have identified the positive impact of MF on the vulnerable groups of the society. It is indeed that microfinance is applauded, but its impact on all dimensions of women empowerment is not uniform. Further, identification of the extent of empowerment numerically is a tedious task. Though, finding out the level of economic empowerment is comparatively easier than any other dimensions of empowerment. At this juncture this study will delve to achieve the following objective.

\section{Objective Of The Study}

The principal objective of this study is to gauge the root causes of the obstacles which are facing by the women microfinance beneficiaries in their empowerment process. This study concentrates on two major areas of challenges of empowerment -

a) From economic front. b) From Social front.

\section{i) Sample Size}

\section{Research Methodology Of The Study}

The questionnaire was administered to a random sample member of 280 SHGs spread in Matigara block under Darjeeling district of West Bengal. The target respondents were only the SHGs under the NRLM who had passed grade I and credit linked with banks. The population of such groups in the area under the study was approximately more than 1025 groups. The sample therefore represented more than $27.31 \%$ of the population.

\section{ii) Methodology of the study}

To reach this objective and to acquire adequate amount of data, a survey was carried out with the NRLM beneficiaries as the target respondents. Before any questionnaire was administered detailed discussions were held with some of the NRLM beneficiaries living in the areas and a pilot survey was carried out. The final structured questionnaire was formulated on the basis of preliminary interviews and pilot surveys. Through the long discussion about the socioeconomic problems of the beneficiaries different peculiar cases have identified. The findings of the study are present in the next section with different cases. This study will prescribe adequate suggestions to overcome these hindrances and it will be a gap filler of the previous studies.

\section{Findings Of The Study}

The findings of the study are presented in different sub-sections. At first it deals with the marketing problems of products which are produced by microfinance beneficiaries. In this regard it would be prudent to highlight the findings of different studies of previous researchers. Micro- finance exponents have realized that marketing is the main problem for the micro enterprises all over the country. Hofstede et al. (1996) argue that working in remote villages far away from market centres limits the scope for identifying and initiating viable income generating activities. Income Generating Activities do not automatically bring overall economic development, but they need markets where people with disposable cash will buy goods and services. Kumaran (2002), Mandal (2005) and Shylendra(2006) found that in absence of proper marketing avenues SHGs were facing hindrances regarding initiating or continuing viable economic activities. Purushotham (2004) found out that in want of innovative marketing support, savings of many SHGs were either under-utilised or unutilised, as these could not be canalised into viable economic avenues. In other study Mishra, Rajput, Mohapatra and Dash (2006) identified that most of the SHG products are sold in local rural hats to the "middle man", who pay very less price to the members, resulting in low income for the group. To get an in-depth idea about the different 
Empowerment of Women Micro Entrepreneurs under NRLM: A Critical Analysis.

trades of economic activities which have been taken up by the sample beneficiaries of catchment area of the study is shown in the following table.

Table No:-I Products produced by the sample SHGs under Matigara Block

\begin{tabular}{|l|c|c|}
\hline \multicolumn{1}{|c|}{ Economic Activities } & No of SHGs & Percentage of Total SHGs \\
\hline Only Agricultural Products & 80 & 28.54 \\
\hline Agricultural along with other works & 39 & 13.93 \\
\hline Only Animal Farming & 48 & 17.14 \\
\hline Animal Farming along with other works & 39 & 13.93 \\
\hline Only Poultry & 4 & 2.43 \\
\hline Poultry along with other works & 8 & 2.86 \\
\hline Handicraft \&Garment Making & 6 & 2.15 \\
\hline Handicraft \& Garment Making along with other activities & 4 & 1.43 \\
\hline Only Nursery & 10 & 3.57 \\
\hline Nursery along with other works & 2 & 0.73 \\
\hline Small Shop & 6 & 2.15 \\
\hline Others Salpata & 34 & 12.14 \\
\hline \multicolumn{1}{c|}{ Total } & $\mathbf{2 8 0}$ & $\mathbf{1 0 0}$ \\
\hline
\end{tabular}

Source: Field survey

From the above table it is found that most of the sample SHGs of Matigara block are engaged in agriculture and animal farming. About 42 percent of the total groups are engaged in Agriculture and about 40 percent of the total SHGs under of this block are engaged in animal Farming. Out of 119 groups who are engaged in agricultural activities, 39 of them are engaged in other works also. On the other hand out of 43 groups who are involved in animal farming, 19 of them are engaged in other works also. It implies that the beneficiaries are not able to manage the economy to generate adequate profit for them and for this reason they have taken up the combination of two or more economic activities at a time to earn money from other sources also. So it is worthwhile to examine the marketing channels of the products which are being produced by the SHGs in this Block.

Table: II Marketing channels for the Sample SHG products under Matigara Block

\begin{tabular}{|c|c|c|c|c|c|c|}
\hline \multirow[b]{2}{*}{ Nature of Work } & \multicolumn{5}{|c|}{ Marketing Channels } & \multirow[b]{2}{*}{ Total No of SHGs } \\
\hline & $\begin{array}{l}\text { Local } \\
\text { Hats }\end{array}$ & $\begin{array}{l}\text { Whole } \\
\text { Sellers }\end{array}$ & Fair & $\begin{array}{c}\text { Govt. } \\
\text { Department }\end{array}$ & $\begin{array}{l}\text { Door to } \\
\text { door }\end{array}$ & \\
\hline Agricultural products & 118 & 8 & - & - & - & 126 \\
\hline Animal farming ( Cow, Goat, Lamb) & 77 & 5 & - & - & - & 82 \\
\hline Poultry & 6 & 4 & - & - & - & 10 \\
\hline Handicraft and Garment making & 14 & 2 & 2 & - & - & 18 \\
\hline Nursery & 2 & - & - & 6 & - & 8 \\
\hline Small shop & 8 & - & - & - & - & 8 \\
\hline Others, (pottery etc.) & 5 & 20 & 3 & - & - & 28 \\
\hline Total & 230 & 39 & 5 & 6 & - & 280 \\
\hline
\end{tabular}

Source: Field Survey

The above table is self explanatory, it depicts that most of the products of SHGs in this area are sold in the local Hatts/ Markets. A few products are sold through wholesalers. These local markets are controlled by the middle men who generally control the market price of the products. As a result the beneficiaries are not able to generate considerable amount of profit by the sale of their products at high price. Only one SHG engaged in handicrafts and Garment Making could sale their product in fair. Almost all the groups engaged in nursery business could sale their products in Government sponsored sales counter and forest department of Government of West Bengal for social forestry. It implies that most of the groups are not getting assistance from Government to sale their product in outside markets. The beneficiaries claimed that if they get proper help from DRDC and other agencies for selling their product in outside market, then they could earn more profitIt implies that most of the groups are not getting help from Govt. to sale their product in outside markets. The beneficiaries claimed that if they get proper help from DRDC and other agencies for selling their product in outside market, then they could earn more profit

Above section clearly depicts that majority of the beneficiaries are involved in traditional sector i.e. chira muri making and agriculture based products and they use to sale it in their local market. Most of the cases they compelled to sale it on credit and they able to realise this money after few days. It signifies that they never get actual market price of their products. Due to inherent characteristic of local market, very often the beneficiaries are not able to exhaust their desire stock and could not able to generate adequate income for them. 
Naturally the women microfinance beneficiaries are lived in a measurable condition. It creates adverse impact on their confidence level and self reliance at their home. Most of the cases male folk of their family could not rely on their activities. In this situation, the male members of their family want to interfere the activities of their female members. To improve their measurable condition generally male folk use to search the alternative source of fund. Most of the cases raise the fund from other sources and mixing it with existing fund which has been raised by their female counterpart. Due to lack of financial literacy, it leads to mishandling of fund and get them into the debt trap. To come out from this situation they use to search another alternative source of fund, by this way they gradually involved in debt swapping. The above statements can be substantiated by the appropriate case vignette which was formulated on the basis of personal interview with the beneficiaries in several occasions. There are several cases of heterogeneous nature was formulated for this study. Due to word restriction of this study only one interesting case is given in the following section.

\section{Case Vignette}

Tagar SHG was formed in 2003 by the combined effort of block and DRDC official with 12 house wife of daily labourer of Atharkhai Gram Panchyat under Matigara block in Darjeeling district. The pooled savings of this group were linked with Uttar Banga Khsetrya Gramin Bank (UBKGB) of Sibmandir branch. After the successful completion of one year two months, they had passed their $1^{\text {st }}$ grading test and received Rs. 15000 as revolving fund from DRDC. The bank had released Rs. 20000 as advance to the group. Asha Roy, one of the needy members had applied for loan from the group. The group members had unanimously sanctioned the loan to the applicant Rs 15000 . She had opened a small grocery shop at her small hut. Initially she could not generate profit from the business as the market is too small. Subsequently her husband has started to interfere on the operation of the enterprise. He took the charge of the enterprise. Afterwards he felt the insufficiency of fund for the improvement of their business. But the female folk could not arrange the required fund from her internal source and she was in trouble to run the business properly. She went to nearby village to convince a member of group which was operated by a private microfinance institution. She had asked the field officer of that MFI to disbursed loan for her Rs. 20000. As per the consent of all the members, who were presented in their weekly group meeting, the field officer of PMFI had collected the loan application form and had given the permission to the group leader to register her name as a member of this group. She had to submit Rs. 220 for loan processing charge and Rs.100 as insurance premium of the loan Rs.20000; it was the precondition of this new loan. Finally Asha Roy had received Rs. 18000 in cash and as per the business policy of this MFI the difference amount i.e. Rs.2000 was kept by the officer as collateral and he had promised that it would be adjusted in time of final repayment of this loan. Loan recovery was started in accordance with the recovery schedule of this MFI. It was weekly instalment system which commenced on immediately after the $1^{\text {st }}$ week of loan disbursement. The beneficiary (Asha Roy) had to pay Rs.460 per week and it must be completed by 52 weeks. It was a great financial problem for her to arrange the requisite fund to repay two loans at a time. She had convinced other members of SHG so that they would allow her to postpone the loan repayment. She had promised that she would repay the loan with adequate interest later on. On the other hand it would become impossible for her to arrange the required fund for weekly instalment Rs. 460 and ultimately she could not pay her $2^{\text {nd }}$ and remaining instalment. Other members of the group had arranged the amount of $2^{\text {nd }} \& 3^{\text {rd }}$ instalment. It is the collection policy of the private MFI that the loan taker has to repay the loan on time by any means without failure. The field officer would not compromise with default. He could not leave the group meeting without full recovery of total weekly instalment amount. All the group members had exercised peer pressure to recover the remaining loan amount from Asha Roy and threatened her to dispose off her valuable property for recovery of balance amount of loan. To come out from this hardship of life she had closedown his previous grocery business gradually and had opened a tiny pan stall at a corner of her hat to sell a part the grocery stock. Members of both the groups had pressurized her to repay the loan with adequate interest as a result she could not able to carry out the pan stall for long time. She was hungering with money and searching for another loan to repay the previous loan from PMFI. At last she could able to convince the field officer of other private MFI about her urgency of loan by suppression of original fact and he had given permission to register herself as a member of an existing group. The field officer had sanctioned Rs. 10000 as loan from this MFI after the payment of Rs.100 as loan processing charge and Rs.100 as insurance premium of this loan. She had received Rs.8500 in cash from this institution though it was sanctioned Rs.10000.This balance amount of $3^{\text {rd }}$ loan Rs. 1500 would be adjusted with the last few instalments. She had used this third loan amount for partly payment of the previous loan of private MFIs. Here also he had to pay weekly instalment Rs. 225 for 50 weeks and it commenced immediately after the $1^{\text {st }}$ week of loan disbursement. After $3^{\text {rd }}$ loan, total outstanding loan was mounted to Rs. 28475 for which she had to pay Rs.685 as weekly instalment towards the MFIs. She could not able to repay any instalment at all and she had arranged required fund from her nearest relatives for first two instalments of $2^{\text {nd }}$ MFI. She had sold out her milch cow for Rs.5000 and had given to the $1^{\text {st }}$ MFI toward repayment of 2nd loan. After all, she had closed down her pan stall and she had taken another mortgage loan from a local moneylender keeping her small hut as 
collateral to repay total loan outstanding amount and she got into debt trap over time. The facts revealed by the beneficiaries demonstrate that marketing is indeed a serious problem which has percolated in the area under the study. For which the women are facing challenges in their economic empowerment process. The significantly positive correlation between economic and social empowerment has been identified many researchers in various occasion. Naturally if the women beneficiaries could not able to empower themselves economically, they will be facing serious problem in their other dimensions of empowerment too.

\section{Conclusions}

It is well recognised that the beneficiaries can reap the benefit of microfinance if and only if they can operate the microenterprises in sustainable manner for long time. The economic status reflects the level of empowerment. This study brings out that microfinance beneficiaries have been facing challenges to generate adequate income for the improvement of their economic status. Due to lack of proper marketing avenues and adequate marketing support from any agency level, the vulnerable rural women could not able to dispose off their stock at actual market price. At the end most of the cases they are accessing multiple sources of finance, i.e., they have also been accessing loans from PMFIs at a time. While they are doing so considering the relative ease of accessing loans from the PMFIs, they also feel that repayment schedules and pressures are creating debt servicing burdens for them. In most of the cases they are unable to meet the debt obligation as per schedule which leads to high rate of delinquency. Beneficiaries are losing their valuable assets, even their house also. Phenomena of over indebtedness and debt swapping are now common features and fund management is now a problem for microfinance beneficiaries. As a result the indicators of women empowerment are moving towards wrong direction. On the basis of the above findings it is suggested that adequate amount of marketing support should be provided by the different agencies so that enterprising women can market their product in appropriate channel and they will be free from the cobweb of the local middleman who use to charge low price of their products. Effective implementation of NRLM can enhance the scope of establishment of economically vibrant microenterprises. It is worthwhile to note that, the NRLM is in infant stage and it will take long time to operate this mission with much vigour. Therefore all concerned agencies should take appropriate measure to run this mission in a befitting manner. If this phenomenon cannot be changed the hindrances in women empowerment will continue and it will lead to disempowerment of women.

\section{References}

[1]. Ahmad, M.A(1999): Women Empowerment: "Self Help Groups", Kurukshetra, April, 1999.

[2]. Banu, D., F. Farashuddin, A. Hossian and S. Akter. (2001). Empowerment of women: The impact of BRAC's rural development programme. Research and Evaluation Division, BRAC, Dhaka

[3]. Carr, M. M. Chen and R. Jhabvala (eds(1997): Speaking Out: Women's Economic Empowerment in South Asia; New Delhi: Vistaar Publications; 1997

[4]. Dubhashi, M. (2002): "Mobilising women SHG through government and non-government organisation" Ashwattha, April-2002, pp. 49-51.

[5]. Ganapathi. R and S. Anbu Malar.(2008): “Consumers Attitude and Preferences towards Self Help Group Products” Asia Pacific Business Review Vo IV, No. 2 April - June

[6]. Hofstede, G., Molenaar, K., Reddy, U. et al. (1996): "Programme Evaluation of Income Generating Activities. Madurai: FACET,1996

[7]. Kabeer, N.(1999):"Conflicts Over Credit: Re-Evaluating the Empowerment Potential of Loans to Women in Rural Bangladesh", World Development 29. 1999

[8]. Kabeer,N.(2003):"Reflections on the Measurement of Women's Empowerment: In Discussing Women's Empowerment-Theory and Practice”, Sida Studies No. 3. Novum Grafiska AB: Stockholm. 2001

[9]. Kulkarni, V.(2002): "Empowerment of women through SHG". Women Link, Jan-April (2002), pp. 32-37.

[10]. Kumaran, K.P.(2002): " Role of SHGs in promoting microenterprises through micro-credit- an empirical study", Journal of Rural Development, Vol 21, No 2, pp231-50

[11]. Mandal,A., (2005): "Swarnajayanti Gram Swarajgar Yojana and SHGs : An assessment", Kurukshetra, Vol 53, No3, pp4-9

[12]. Manimekalai, D. (2004): "Economic empowerment of women through SHG”. Third Concept. February 2004, pp. 47-50.

[13]. Manimekalai, M. \& Rajeshwari, G.(2004): "Nature And Performance Of Informal Self Help Groups - A Case From Tamil Nadu", Indian Journal Of Agricultural Economics, Vol. 56 (3), July-Sept, 2004.

[14]. Mayoux, L. (2000): Microfinance and the empowerment of women: A review of the key issues. Social Finance Unit Working Paper, 23, ILO, Geneva.

[15]. Mayox Linda (1999): “The Magic Ingredient- Micro finance and Women's Empowerment” www.gdrc/icm/magic/html

[16]. Mishra Sanjeeb Kumar, Rajput N.B.S, Mohapatra P.K, Dash R.K (2006): "E-Grama: The Rural Information Gateway of Ganjam District (Orissa), In Promise of e-Governance operational challenges, M.P.Gupta (eds.), TMH, 2006, pp. 540-546.

[17]. Montgomery, R. (1996): "Disciplining or protecting the poor? ---in Microcredit schemes". Journal of International Development, Vol-8, No-2.

[18]. Pattanaik, B.K. (2001): “Gender Economic Empowerment and rural poverty alleviation”. Kurukshetra. December 2001. Pp.36-40.

[19]. Pitt, M., S. R. Khandker, and J. Cartwright. 2006. Empowering Women with MicroFinance: Evidence from Bangladesh, Economic Development and Cultural Change, 791- 831.

[20]. Puhazhendi, V. and Satyasai, K.J.S., 2001: "Economic and social empowerment of rural poor through SHGs", Indian Journal of Agricultural Economics, Vol. 56. No. 3.

[21]. Purushotham, P: "Marketing support for the SHGs". Kurukshetra, February 2004, vol. 52, no. 4, pp. $23-28$. 
[22]. Rangi, P. S, Sighu, M. S. and Singh, Harjit (2002): "Economic empowerment of rural women through SHG: a case study of Fatehgarh Sahib District (Punjab)". Man \& Development, September 2002.

[23]. Sarkar, S(2005): "Self Help Groups and Non Traditional Products: - A Study of Micro Enterprises in North Bengal". Indian Journal of Millennium Developments studies: An International Journal.Volume1. No.1 March 2006

[24]. Schuler, S. R., S. M. Hashemi, A. P. Riley, and A. Akhter (1996).: "Credit Programs, Patriarchy and Men's Violence against Women in Rural Bangladesh.” Social Science and Medicine 43, no. 12 (1996): 1729-42.

[25]. Sen, A(2003): "Gender and Cooperative Conflicts." In Persistent Inequalities: Women and World Development, ed. I. Tinker. New York: Oxford University Press, 2003.

[26]. Shylendra, H.S. (2005): "The SHG bank linkage programme: An assessment and future strategies". Journal of Rural Development. Vol-23 (4), pp. 411-433.

[27]. Shylendra, H.S. (2006):“Microfinance Institutions in Andhra Pradesh: Crisis and Diagnosis”, Economic and political Weekly, Vol XLI, No20, May

[28]. United Nations Development Programme. (2001): Participatory governance, people's empowerment and poverty reduction. UNDP Conference Paper Series.

[29]. Vijayanthi, K. N. (2002) (Research Note): "Women's empowerment through SGH: a participatory approach". Indian Journal of Gender Studies (2002), pp. 263-73

[30]. World Bank, 2001: Engendering Development: Through Gender Equality in Rights, Resources, and Voice - Summary, Washington. www.worldbank.org/gender/prr/

[31]. Zaman, H.(1999): "Assessing the poverty and vulnerability impact of micro-credit in Bangladesh: a case study of BRAC", unpublished background paper for World Bank, World Development Report (Washington, World Bank) http://www.worldbank.org/html/dec/Publications/Workpapers.

[32]. Zeller, M. (2000): On the safety net role of microfinance for income and consumption smoothing. In Shielding the poor: Social protection in developing countries, ed. N. Lustig. Washington, DC: Brookings Institution and Interamerican Development Bank.. 